\title{
Gerçek Kişiler Yönünden Kişiliğin Sona Erme Halinin Türk Vergi Sistemindeki Etkisi
}

\section{The Effect of Personal Personality Termination in Terms of Real Persons on the Turkish Tax System}

Taner Ercan ${ }^{1}$

RESEARCH

ARTICLE

\section{ARTICLE INFO}

Submitted : 29.07.2021

Revised : 23.09.2021

Accepted : 25.10.2021

Available : 25.12.2021

iThenticate similarity

score: $4 \%$

JEL classification:

$\mathrm{H} 20, \mathrm{H} 24, \mathrm{~K} 34$

Keywords:

Person, personality, death, tax, inheritance, inheritor

\begin{abstract}
A B S T R A C T
The concept of person, which is the main subject of all branches of law, has an important place in the world of law. Because the person is the owner and subject of the rights and obligations regulated by the rules of law. A human being is accepted as a person by birth and depending on this aspect, he has the capacity to have rights. In the ordinary course of life, the rights that depend on the person may be terminated in various situations. Person and personality related rights, their beginning and end are expressed in the context of the Turkish Civil Code. In this respect, the person who is determined as the inheritor with the termination of the personality in the form and/or situations specified in the laws cannot establish new legal transactions in the legal order. However, following the termination of the personality, some legal actions may need to be completed. One aspect of the legal proceedings within this scope is the effects of death (termination of personality) on the Turkish Tax System. In other words, in case of death, the tax transactions of the deceased will have to be carried out for the heirs whose refusal has not been inherited, for the new liability that will occur after death. The article was examined in a purposive, complementary and descriptive framework, and the death of the taxpayer and the features that emerged in the Turkish Tax System were emphasized, and the effects of the termination of the personality on the current legislation were revealed. In this context, the effects of the termination of personality within the framework of natural persons will be evaluated in the eyes of the laws within the scope of the Turkish Tax System.
\end{abstract}

Cite this article as: Ercan, T. (2021). "Gerçek Kişiler Yönünden Kişiliğin Sona Erme Halinin Türk Vergi Sistemindeki Etkisi", International Journal of Public Finance, 6(2), 291-311.

\footnotetext{
${ }^{1}$ Assist Prof. PhD., Kırklareli University, Department of Public Finance, ORCID: 0000-0001-9647-0127, taner.ercan@klu.edu.tr
} 
Ercan, T. (2021). “Gerçek Kişiler Yönünden Kişiliğin Sona Erme Halinin Türk Vergi Sistemindeki Etkisi”, International Journal of Public Finance, 6(2), 291-311.

\begin{tabular}{l} 
MAKALE Bígisi \\
\hline Gönderme: 29.07 .2021 \\
Düzeltme $: 23.09 .2021$ \\
Kabul $\quad: 25.10 .2021$ \\
Yayın : 25.12 .2021 \\
\hline iThenticate benzerlik \\
oranı: \%4 \\
\hline JEL Kodu: \\
H20, H24, K34 \\
\hline
\end{tabular}

Anahtar Kelimeler:

Kişi, Kişilik, Ölüm, Vergi, Veraset, Mirasçı

\begin{abstract}
ÖZET
Tüm hukuk dallarının temel süjesini teşkil eden kişi kavramı, hukuk dünyasında önemli bir yere sahiptir. Çünkü kişi, hukuk kuralları vasıtasıyla düzenlenen hak ve yükümlülüklerin sahibi ve konusunu teşkil etmektedir. Insan doğum ile birlikte kişi olarak kabul edilmekte ve bu yönüne bağı olarak da hak ehliyetine sahip olmaktadır. Kişiye bağı olan hakların hayatın olağan akışı içerisinde çeşitli hallerde sona ermesi söz konusu olabilmektedir. Kişi hakları kanun koyucu aracılı̆ıılla ayrıntılı bir şekilde yasalarda hüküm altına alınmıştır zira kişiliğin son bulması sonrası yasal kapsamda yeni bir dönem başlamaktadır. Kişi ve kişiliğe bağlı haklar, bunların başlangıcı ve sona ermesi Türk Medeni Kanunu bağlamında ifade edilmektedir. Bu minvalde kişiliğin yasalarda belirtilen şekil ve/veya durumlarda son bulması ile muris olarak belirlenen kişi, hukuk düzeninde yeni hukuksal işlemler tesis edememektedir. Ancak kişiliğin sona ermesine müteakip bazı yasal işlemlerin ikmal edilmesi gerekebilmektedir. Ölüme bağlı bu durum, medeni kanun çerçevesinde miras hukuku vasıtasıyla tekemmül etmektedir. Bu kapsamdaki hukuksal işlemlerin bir yönünü de ölüm (kişiliğin sona ermesi) halinin Türk Vergi Sisteminde oluşan sonuçları oluşturmaktadır. Yani ölüm halinde murise ait vergisel işlemlerin, reddi mirasta bulunmamış mirasçılar tarafından ölüm sonrası oluşacak yeni mükellefiyete yönelik işlemlerin gerçekleştirilmesi gerekecektir. Makale amaçsal, tamamlayıcı ve betimleyici çerçevede irdelenerek mükellefin ölümü ile Türk Vergi Sisteminde ortaya çıkan özellik içeren hususlar vurgulanmış, kişiliğin sona ermesinin mer'i mevzuatta olan etkileri ortaya konmuştur. Bu minvalde çalışmada, gerçek kişiler çerçevesinde kişiliğin sona ermesinin Türk Vergi Sistemi kapsamında yer alan kanunlar nezdinde ortaya çıkardığı etkiler değerlendirilecektir.
\end{abstract}

\section{Giriş}

Kişi, hukuk düzeninde hak sahibi, yükümlülük altına girebilen ve haklara haiz olan varlığı ifade etmektedir. Hukuk dünyasında hakların temel konusunu oluşturan kişi kavramı, hukuki zeminde hakların tanınması açısından ayrı bir öneme sahiptir. Çünkü hukuksal zeminde hakların tanınması gerekli muhatap kişinin belirlenmesi suretiyle tekemmül etmektedir. Ancak doğal olarak bu süreçte tüm varlıkların hak ve borçlara sahip olması mümkün değildir ve bu doğrultuda hak sahibi olacaklar ve iradi olarak borç altına girebilecekler kanun koyucu iradesi çerçevesinde şekillenmektedir. Her insan hukuki bağlamda kişi olarak değerlendirilmekte olup sağ ve tam doğma koşulu ile birlikte hak ehliyetine, yasalarda belirlenen şartların taşınması durumunda da fiil ehliyetine sahip olmaktadır. Bu minvalde medeni kanun kapsamında hak ve borçlara sahip kişi, yaşamın gerçeklerinden birisi olan ölüm hali ile de bir gün karşılaşmaktadır. Kişiliğin sona ermesi anlamına gelen ölüm ile birlikte hukuk âleminde murisin herhangi bir hukuksal tasarrufta bulunma olasılığı kalmamaktadır. Türk Medeni Kanunu'nda (TMK) kişiliğin başlaması ve sona ermesi halleri "kişi hukuku" temelinde belirtilmiştir. 
Ölüm de doğum gibi birçok farklı hukuksal düzlemde sonuçlar oluşturmakta, ölüm hali ile şahsiyetin sona erme durumu gerçekleşmektedir. Murisin malvarlığına ve ölümünden önceki vergi mükellefiyetine yönelik olarak vergisel alanda yeni bir süreç başlamaktadır. Hukuk düzeninde kişiliği sona eren murisin reddi mirasta bulunmamış kanuni ve mansup mirasçıları miras hukuku çerçevesinde bazı hak ve yükümlülüklerle karşı karşıya kalınmaktadır. Ölüm veya gaiplik ile kişiliği sona ermiş murisin geçmişteki vergisel olan ve olmayan bütün borç ve yükümlülükleri mirasçılara külli halefiyet kuralına göre geçer. Ayrıca mirasçılara veraseten intikallerde vergisel yükümlülükler de doğmaktadır. Diğer yandan reddi mirasta bulunmamış mirasçıların murisin vergi mükellefi olması, muris kişiye ait işletmesinin bulunması, sağlığında sahip olduğu şirket hisselerine sahip olması hallerinde vergisel maddi ve şekli yönlerden yükümlülükleri meydana gelmektedir. Bahsi geçen yükümlülüklerin yerine getirilmesi esnasında Türk Vergi Sistemi (TVS) dâhilinde oluşan sorumlulukların da yasal zeminde yerine getirilmesi önem arz etmektedir.

Kişiliği sona eren vergi mükellefi murisin uhdesinde vergi ödevine yönelik Türk Vergi Sisteminde (TVS) ortaya çıkan vergisel etkilerin de mirasçılar tarafından dikkate alınması gerekmektedir. Çünkü bu durumunun TVS'de çerçevesinde bulunan kanunlar bünyesinde çok çeşitli etkileri olmaktadır. Başta Vergi Usul Kanunu olmak üzere Gelir Vergisi Kanunu, Katma Değer Vergisi Kanunu, Veraset ve İntikal Vergisi Kanunu ve Amme Alacakları Tahsil Usulü Hakkında Kanun kapsamında kişiliğin sona erme halinin mirasçılar açısından önemli düzeyde etkileri olmaktadır. Bu çalışmada kişiliğin ölüm ya da gaiplik vasıtasıyla sona ermesi ile birlikte Türk Vergi Sistemi çerçevesindeki yasalar doğrultusunda ortaya çıkan vergisel hak ve ödevlerin değerlendirilmesi amaçlanmıştır.

\section{Medeni Kanun Çerçevesinde Kişi Kavramı}

Kişi mefhumu etimoloji çerçevesinde irdelendiğinde şahıs, kimse, insan, eş gibi kelimelerle ifade edildiği görülmektedir. Kişi sözcüğü ayrıca birçok farklı dilde de değişik biçimlerde telaffuz edilmektedir. Latincede "persona", Fransızcada "personne", Ingilizcede "person" olarak dile getirilmektedir. Türkçede ise genellikle Arapça kökenli olan "şahıs" terimi kişi kavramı yerine kullanılmaktadır. Ancak yeni Türk Medeni Kanunun'un yürürlüğe girmesi ile birlikte şahıs terimi yerine kişi terimi kullanılmaya başlanmıştır (Ergün, 2017: 4). Kişi, hak olarak nitelendirilen bir imtiyaz biçimine sahip olan varlığı temsil etmektedir. Hukuksal platformda her insan kişi olarak ifade edilmektedir. Çünkü hukuksal statüde kişi, hak sahibi olan ve hak süjesi olarak değerlendirilmektedir. Bu bağlamda hukuk âleminde hak ve borçlara sahip olma yetisi, ehil olma kudreti tanınan varlıklar "kişi” olarak tanımlanmaktadır (Budak, 2011: 8).

Hukuk normları hakları tanımlarken hakların konusu olan "kişi” unsurunun da göz önüne alınması ve hukuksal süreçte bu durumun belirlenmesi bir zorunluluk olarak addedilmektedir. Hukuk düzeninde hak ve borçlara sahip yani hak ehliyetine sahip kişi kavramı sadece doğada var olan insanı ifade etmemektedir (Akipek \& Akıntürk, 2002: 
228). Hak ve borçlar tanımlanırken tabiatta var olmayan fakat hayatın olağan akışı içerisinde bulunan, sosyal ve ticari yaşamın gerekli kılmasından dolayı hak tanınan soyut yapılar da değerlendirilmektedir. Bu yapılar gerçek kişiler gibi birtakım hak ve borçlara sahip olmakla birlikte söz konusu varlıklar hukuk düzeninde "tüzel kişi” olarak ifade edilmektedir. Yani hukuk nizamı tabiatta fiili olarak var olan gerçek kişiyi hak sahibi olarak görürken diğer taraftan sosyal yaşamın izdüşümünden yola çıkarak "insan ve mal topluluklarını" da (yasalarda belirtilen kurallara uymak şartıyla) tüzel kişi olarak tanımlamıştır (Budak, 2011: 2).

Hukuk düzenini korumak adına hareket eden kanun koyucu hangi varlığı kişi olarak kabul edip etmeyeceğine ve haklar verip vermeyeceğine karar vermektedir. Bu kararı verirken toplumun etik düşünce yapısı ve yasa yapma stratejisi çerçevesinde hareket etmekte ve kişi olarak tanımladığı varlığa hak sahibi olma ehliyeti tevdi etmektedir. Böylece hayatın içerisinde ifade edilen kişi, hukuk düzeninde belirtilen anlamda "kişi" olarak tanımlanmakta dolayısıyla hak ve borçlara sahip olma kabiliyetini ortaya koyan "hak ehliyeti"ne de sahip olmaktadır (Akıntürk \& Karaman, 2010: 108). Kişilik kavramı ise kişi olunması hasebiyle haiz olunan bütün hakların tekemmül edildiği hukuki vaziyeti ifade etmektedir (Kirazcı, 2011: 15). Kişiliğin dar ve geniş anlamda tanımı yapılabilmektedir; dar çerçevede kişilik, hak ve borçlara haiz olma yetisini yani hak ehliyeti olarak nitelendirilmektedir. Geniş manada ise, hak ehliyetinin yanında ayrıca fiil ehliyetini, "medeni hakları kullanabilme" kavramını da içermektedir. Bu cihette kişilik mefhumu kişi kavramından daha etraflı bir anlama gelmekte olup hak ve fiil ehliyetlerini, kişilerin durumlarını ve sahip oldukları hakları içermektedir. Yani kişiye sıkı sıkıya bağlı ve hukuk düzeni ile korunmakta olan tüm maddi, manevi ve hukuki karşılıkları kapsamaktadır (Öcal, 2016: 31). Bir kişinin medeni durumu çerçevesindeki evli ya da bekâr olması hali, ergin ya da mahcur olması kişisel durumları ile ilgilidir. Diğer yandan kişinin mutlak haklar maddi, manevi ve ekonomik kapsamdaki hakları kişilik haklarının ifade etmektedir. Örneğin, mesleğinde önemli bir kariyere sahip avukatın izni olmadan isminin yeni açılacak uluslararası bir hukuk şirketinde zikredilmesi ve reklama konu edilmesi avukatın kişilik haklarına muhalif bir durumdur (Öcal, 2016: 32).

Kişiler hukuku Medeni Hukuk çerçevesinde değerlendirilmekte ve kısaca kişilerin hukuki durumlarını düzenlemektedir. Medeni Hukuk, kişiler arasındaki hak ve yükümlülükleri tesis eden, belirli kapsamda kişilerin doğru veya dolaylı olarak özel hukuk minvalindeki ilişkilerinin başka bir hukuk dalının konusuna dâhil olmayan şekilde düzenleyen hukuk dalı olarak nitelendirilmektedir. Ayrıca medeni hukuk, "kişiler hukuku, aile hukuku, miras hukuku, eşya hukuku ve borçlar hukuku" dallarına ayrılmaktadır (Oğuzman vd., 2020: 1). Kişiler Hukuku, 4721 sayılı Türk Medeni Kanunu'nun birinci kitabında düzenlenmektedir. Türk Hukuku diğer çağdaş hukuk düzenlerinde olduğu gibi insana insan olduğu için hak ehliyetini tanımakta ve hak ve borçların aktif süjesi olarak insanı nitelendirmektedir. Bu durum TMK'nın 8. maddesinde belirtilen hak ehliyeti çerçevesinde ifade edilmiştir. TMK'ya göre kişiliğin başlaması insanın tevellüdü ile vuku bulmakta, sağ ve tam olarak doğan insan bu 
vasfından dolayı hukuk âleminde hak ehliyetine sahip bir kişi olarak yer almaktadır. Bu konu TMK'nın 28. maddesinde kişiliğin başlaması şu şekilde belirtilmiştir "Kişilik, çocuğun sağ olarak tamamıyla doğduğu anda başlar ve ölümle sona erer. Çocuk hak ehliyetini, sağ doğmak koşuluyla, ana rahmine düştüğü andan başlayarak elde eder". "Sağ doğum şartı" olarak ifade edilen hal, çocuğun ana rahminden ayrılarak bir an bile yaşaması ile vukuu bulmaktadır. Tam olarak doğma durumu ise çocuğun ana rahminden ayrı bir şekilde bağımsız bir insan olarak fiiliyat kazanmasını ifade etmektedir (Gök \& Akçay, 2012: 158). Yasada belirtilen şekilde sağ ve tam olarak doğmuş, kişi olarak hukuk düzeninde yer almış "kişi", hak ehliyetine ("medeni haklardan yararlanma ehliyeti") sahiptir. Ayrıca "medeni hakları kullanma ehliyeti" olarak benimsenen "fiil ehliyeti"ne de kanunda belirlenen şartları taşıması halinde sahip olmaktadır. Hak ehliyeti TMK 8. maddesinde ifade edildiği üzere insan olma vasfından dolayı nitelendirilen bir haktır. Fiil ehliyet ise şahsi fiil ve işlemleri dolayısıyla haklara sahip olma ve borç yükü altına girebilme imkânı tanıyan bir ehliyettir. Bu konuda TMK'nın 9. maddesinde gerekli tanım yapılmıştır "Fiil ehliyetine sahip olan kimse, kendi fiilleriyle hak edinebilir ve borç altına girebilir" (Resmi Gazete, 2001/4721: 9). Hak ehliyeti pasif bir ehliyet olarak kabul edilmekte ve bütün kişiler açısından eşit ifade edilmektedir. Diğer yandan fiil ehliyeti ise aktif bir ehliyet olup kişinin gerçekleştirdiği tasarruflara yönelik hüküm ve sonuçlar şahsın uhdesinde vukuu bulmaktadır. Fiil ehliyeti yasada birtakım şartlara bağlanmıştır ve bu koşullara sahip olanlar fiil ehliyetine haiz olabileceklerdir. Çünkü herkesin eş zamanlı olarak ve aynı biçim ve şekilde akıl sağlığı, psikolojisi ve bedensel bütünlüğü tam olmayabilmektedir (Gök \& Akçay, 2012: 159). Fiil ehliyetine sahip olmanın yasada belirtilen şartları şu şekilde ifade edilebilir; ergin olmak, ayırt etme gücüne haiz olmak ve kısıtlı olmamaktadır. TMK'nın 10. maddesinde ayırt etme gücü belirtilmiştir, buna göre "Ayırt etme gücüne sahip ve kısıtlı olmayan her ergin kişinin fiil ehliyeti vardır" (Resmi Gazete, 2001/4721: 10). Diğer bir koşul ise ergin olmaktır ve hukukumuzda ergin olma hali özel durumlar hariç 18 yaşının tamamlanması ile tekemmül etmektedir, bu konudaki hususlar TMK'nın 11. ve 12. maddelerinde tanımlanmıştır. TMK'nın 13. maddesinde ise ayırt etme gücünün kapsamı belirtilmiştir. Yasada belirtilen koşullara haiz olanlar tam ehliyetli olarak ifade edilmektedir. Fiil ehliyetinde yasada belirtilen şartlardaki eksiklik ya da hayatın olağan akışı içerisindeki kayıplar, kişiyi ehliyetsiz kılabilmekte veya belirli hakları kullanımı konusunda sınırlayabilmektedir. Bu ve benzeri kapsamdaki durumlara göre kişiler "tam ehliyetliler, sınırlı ehliyetliler, tam ehliyetsizler ve sınırlı ehliyetsizler" olmak üzere ayrılmaktadır. Tam ehliyetlileri ayırt etme gücüne haiz, ergin olan ve kısıtlanmamış olan kişileri ifade etmektedir. Sınırlı ehliyetliler, şahıslarına yasal danışman ataması yapılmış ve evli olan kişilerdir. 213 sayılı Vergi Usul Kanunu'nun (VUK) 9. maddesi gereğince ise "Mükellefiyet ve vergi sorumluluğu için kanuni ehliyet şart değildir" ifadesi yer almaktadır. Yani hak ve/veya fiil ehliyetine haiz olmayan kişi dahi vergi mükellefi olabilmektedir. TMK'da ayırt etme gücüne sahip olmayan kişiler tam ehliyetsizler olarak kabul edilmektedir. Sınırlı ehliyetsizler ise ayırt etme gücüne sahip olup küçük ve kısıtlılar olarak yasada belirtilmektedir. 
Kanunlarda belirtilen hak ve borçlara sahip, bu hakların kullanımı çerçevesinde tespit edilen ehliyete sahip kişi, yasadan kaynaklanan haklarını yaşamı boyunca kullanmaktadır fakat söz konusu durumun sona ermesi yani kişiliğin sonlanması bu süreçte farklı şekillerde gerçekleşebilmektedir (Oğuzman vd., 2020: 17). Kişiliğin sona ermesi başta ölüm ile vukuu bulmaktadır ayrıca ölüm dışında ölüm karinesi ve gaiplik olmak üzere iki farklı biçimde de nihayetlenebilmektedir. Söz konusu durumun gerçekleşmesi kişi üzerinde doğum ile kazanılmış olan hak ehliyetini ve kişinin yasada belirtilen koşullar vasıtasıyla sağlamış olduğu fiil ehliyetini de ortadan kaldırmaktadır (Arat, 2006: 259). Ölüm, hayatın sona erme hali olduğundan kişiye bağlı olan hakların da doğal olarak sona ermesi söz konusudur. Yani kişinin medeni hakları kullanma konusundaki haklarının yanında maddi, manevi, fiziki, kariyeri ve ekonomik durumuna dâhil olan ve kişiye sıkı sıkıya bağlı haklar da ortadan kalkmaktadır. Fakat kişiye ait olan para ve para ile ölçülebilen birtakım değerleri kaldıysa bunlar da mirasçılara intikal etmektedir (Arat, 2006: 260). Ölüm karinesi ise, kişinin ölümüne yönelik ispatı kolaylaştırmak amacıyla kullanılan bir kavramdır. Karine, "bilinen bir durum veya olgudan bilinmeyen bir duruma ilişkin sonuç çıkarmaktır". Ölüm halinin somutlaşması cesedin fiziki olarak bulunması, ölen kişinin kim olduğunun belirlenmesi açısından önemlidir. Ancak her zaman bu durum gerçekleşmeyebilir yani fiziki ya da gözle görülebilir bir halde ölümün tespiti olanak dâhilinde olmamaktadır. Kişinin ölümü kesin olarak bakılan bir olay içinde vukuu bulmuş, ortadan kaybolmuş ve cesedinin bulunamaması halinde ölüm karinesi söz konusu olmaktadır. Ayrıca adi karine hükmünde olan, birbirinin mirasçısı kişilerin ölümüne muhakkak olacak bir durumda cesetlere ulaşılamaması hali de birlikte ölüm karinesi olarak ifade edilmektedir (Oğuzman vd., 2020: 27-28). Gaiplik, ölümün muhtemel olduğu ancak ölümün ispatının yapılamaması durumlarında gaip kişinin "hak ve malvarlığının hareketsiz bırakmamak", hakları ölüme bağlı olan hususları askıda bırakmak amacıyla düzenlenmiş bir kurum olarak kabul edilmektedir (Arat, 2006: 266). Gerek gaiplik, gerekse ölüm karinesine dayanarak ölüm halinin vukuu bulması, medeni kanun ve diğer kanunlar nezdinde murisin kişiliğinin, sağlığında sahip olduğu haklarının sona ermesi anlamına gelmektedir. Gaiplik kararının verilmesi süreci 1 ile 5 yıl arasında sonuçlanmakta olup bu süreçte gaip olması muhtemel kişinin mal varlığı TMK'nın 427. maddesi gereğince vesayet makamının yönetim ve yükümlülüğüne verilir. Ayrıca TMK'nın 462. maddesine göre vesayet makamının vereceği özel yetki ile gerekli hallerde kayyıma dava açma, sulh olma, konkordato ve borç ödemeden aciz beyanında bulunma imkanları tanınabilmektedir. Gaiplik sürecinde ölüm tehlikesi içerisinde kaybolma halinde 5 yıl, uzun zamandır haber alınamama durumunda 15 yıllık sürelerin dolması ile teminat, kişisel kefaletler sona ermektedir. Ayrıca tereke herhangi bir şarta bağlı olmaksızın reddi mirasta bulunmamış mirasçılara intikal etmektedir. Ancak söz konusu süreler dolmuş olsa bile hak sahibi gaibin zuhuru gerçekleşebilmektedir. Bu durumda mirasçılar TMK 585/1'e göre terekeye ait olan malları (zilyetlik kurumu gereği) gaibe geri vermekle yükümlü olmaktadırlar. 


\section{Türk Vergi Hukukunda Kişi Mefhumu}

Gerçek kişi kavramı ve kişiye ait haklar ve bu hakların kullanımına yönelik esaslar TMK'da belirtilmiştir. Dolayısıyla mevzuatımızda kişi ve kişilik kavramlarının gerçek hayata yansıması TMK kapsamındaki değerlendirmeler çerçevesinde düşünülmektedir. Türk Medeni Kanunu'nda kişiler gerçek ve tüzel kişiler olarak belirlenmiştir, vergi hukukunda da vergiyi doğuran olay ile ilişki içine giren kişiler doğal olarak mükellef statüsünde addedilmektedir (Budak, 2011: 45). Medeni hukuk çerçevesinde yer alan kişi ile vergi hukuku kapsamındaki mükellef söz konusu durum içeriğinde benzerlik göstermektedir. Ancak kişi kavramı, kişiye yönelik hak ve borçlar ve bunların ifası, sorumlulukları açısından Türk Vergi Hukuku'nda birtakım farklılıklar da arz etmektedir (Oğuzman vd., 2020: 286). Medeni Kanun açısından kişi olarak nitelendirilmeyen belirli teşekküller, vergi hukuku bağlamında vergi mükellefi olarak değerlendirilmiştir. Dolayısıyla medeni hukuk çerçevesinde hak ve fiil ehliyetine sahip olmayan söz konusu teşekküller, vergi ehliyetine sahip kılınmalarından dolayı vergi yükümlüsü olabilmektedir. Vergi ehliyetine sahip olma hasebiyle vergisel düzlemde "vergi kişiliği" oluşan hukuki mevcudiyetler vergi mükellefi olarak ifade edilmektedir. Bu durum "vergi hukukunun bağımsız bir hukuk disiplin dalı" olmasından ve vergi hukukuna has kuralların bulunmasından kaynaklanmaktadır. Ancak medeni hukuk çerçevesinde değerlendirildiğinde kişiliğe haiz olmayan teşekküllere vergisel düzlemde "kişilik" kavramının atfedilmesi halinin diğer hukuk kuralları kapsamında bağlayıcılığı bulunmamaktadır (Şenyüz vd., 2021a: 87). Kurumlar vergisi kanununda konuya yönelik örnek olarak cemaatler, iş ortaklıkları ve yatırım fonlarının tüzel kişiliğe sahip olmamasına rağmen vergiyi doğuran olay ile ilişki kuracak bir faaliyette bulunmaları, kurumlar vergisi mükellefi olmalarına sebebiyet verebilecektir. Ayrıca 5520 sayılı Kurumlar Vergisi Kanunu'nun 2. maddesinde ismen bahsi geçen teşekküllerin tüzel kişiliğe haiz olmamalarının mükellefiyet durumlarını menfi bir şekilde etkilemeyeceği şu şekilde hüküm altına alınmıştır "iktisadî kamu kuruluşları ile dernek veya vakıflara ait iktisadî işletmelerin kazanç amacı gütmemeleri, faaliyetlerinin kanunla verilmiş görevler arasında bulunması, tüzel kişiliklerinin olmaması, bağımsız muhasebelerinin ve kendilerine ayrılmış sermayelerinin veya iş yerlerinin bulunmaması mükellefiyetlerini etkilemez. Mal veya hizmet bedelinin sadece maliyeti karşılayacak kadar olması, kâr edilmemesi veya kârın kuruluş amaçlarına tahsis edilmesi bunların iktisadî niteliğini değiştirmez". Bu minvalde her gerçek veya tüzel kişi vergi mükellefi olabilmekte ancak her mükellefin gerçek veya tüzel kişi olma zorunluluğu bulunmamaktadır. 3065 sayılı Katma Değer Vergisi Kanunu (KDV) medeni kanunda kişi olarak addedilmeyen adi ortaklıkları, vergi hukuku kapsamında bağımsız bir işletme hükmünde vergi mükellefi olarak nitelendirilmektedir. Eğer adi ortaklık nezdinde KDV'nin ödenmeme durumu söz konusu olursa ortaklardan her biri müteselsilen tarhiyat ve ödeme ile ilgili yükümlüdür. $\mathrm{Bu}$ yüzden gerçek ve tüzel kişilerin mükellefiyetleri vergi hukuku açısından farklı özellikler arz etmektedir (Şenyüz vd., 2021a: 87). 
Vergi mükellefiyeti, vergilendirme sürecinin muhatabı, hak ve ödevlere haiz olan kişiyi ifade etmektedir. Çünkü vergi, kişilerle devlet arasında tekemmül eden vergiye yönelik ilişkiler bütününü açıklamaktadır (Guzy, 2017: 71). Vergi hukukunda da gerek mükellefiyet gerekse vergi sorumlulukları kişi kavramı ile şekillenmektedir. Dolayısıyla vergi mükellefi de "kişi-birey" kapsamında düşünülmektedir. Yani vergiyi doğuran olayla ilişkide bulunan mükellef, medeni hukuk çerçevesinde "kişi" kavramından hemen sonra gelmektedir (Öncel vd., 1985: 82). Bu yüzden mükellefiyetin tekemmül etmesi medeni hukukta belirtilen hak ve fiil ehliyeti çerçevesinde gerçekleşmemekte, vergi ehliyeti mükellefiyet tesisi için yeterli olmaktadır (Budak, 2011: 46). Gerçek kişi olup medeni hakları kullanma açısından fiil ehliyetine haiz olanlar doğal olarak vergi hukuku kapsamında belirtilen tüm yükümlülükleri yerine getirmekle sorumludurlar. Fakat fiil ehliyeti olmayan kişilerin de mükellef olma durumu söz konusu olabilmektedir ve bu kişilerin vergisel yükümlülüklerini ve haklarını kullanmaya yönelik ehliyetleri yoktur. İlgili kişiler, bu niteliklerinden dolayı sahip oldukları haklarını fiili hayata yansıması yasal temsilcileri vasıtasıyla gerçekleştirilmektedir. Yani fiil ehliyetinin kişi nezdinde olmaması vergi hukuku açısından mükellefiyete engel değildir. Ergin olmayan, kısıtlı olan ve ayırt etme gücüne sahip olmayanlar dahi vergiyi doğuran olay ile bağlantı içine girdiklerinde mükellef sayılmakta, sorumlulukları kanuni temsilcisi tarafından yerine getirilmektedir. Örnek olarak mirasın küçük bir çocuğa yani fiil ehliyeti olmayan bir gerçek kişiye kalması durumunda beyanname verme, vergi ödeme gibi vergisel yükümlülüklerini yasal temsilcisi yerine getirmek durumundadır (Şenyüz vd., 2021a: 88).

Medeni hakları kullanma ehliyetine sahip olmayan kişiler vergi hukuku kapsamında belirtilen vergi ehliyetine haiz olmakla mükellefiyet kazanabilmektedirler. Bunun sebebi vergi hukuku çerçevesinde kabul edilen ehliyet kriterinin vergiyi doğuran olayla bağlantı içinde olmaktır. Bu durum 2709 sayılı Türkiye Cumhuriyeti Anayasası'nın 73. maddesinin 1. fıkrasında ifade edilmiştir "Herkes, kamu giderlerini karşılamak üzere, mali gücüne göre, vergi ödemekle yükümlüdür". Mali güce sahip herkes yasalarda belirtilen çerçevede mükellef olabilmektedir. Bu durumda "mükellefiyet ve vergi sorumluluğu için hukuki ehliyetin (fiil ehliyeti, kanuni ehliyet, medeni hakları kullanma ehliyeti) gerekli olmamasında "vergi ehliyeti" adı verilmektedir" (Budak, 2011: 49). Yani fiil ehliyeti, yasal ehliyet, kendi adına borç altına girebilme gibi haklara haiz ehliyete sahip olmadan vergiyi doğuran olay dâhilinde olunması hali vergi ehliyetini tarif etmektedir (Budak, 2011: 46). Bu bağlamda 10703 sayı ve 1961 tarihli 213 sayılı Vergi Usul Kanunu'nun 8. maddesinde verginin konusuna giren bir işlem ya da faaliyete dâhil mükellef olarak adlandırılan kişinin vergisel yükümlülüğüne yönelik düzenleme yapmıştır, buna göre "Mükellef, vergi kanunlarına göre kendisine vergi borcu terettüb eden gerçek veya tüzel kişidir. Vergi sorumlusu, verginin ödenmesi bakımından, alacaklı vergi dairesine karşı muhatap olan kişidir. Vergi kanunları ile kabul edilen haller müstesna olmak üzere, mükellefiyete veya vergi sorumluluğuna müteallik özel mukaveleler vergi dairelerini bağlamaz. Bu kanunun müteakip maddelerinde geçen mükellef tabiri vergi sorumlularına da şamildir". Diğer yandan yine 
VUK'un 9. maddesinde mükellefiyetin tesis edilmesi sürecinde yasal ehliyetin gerekli olmayacağına dair hüküm bulunmaktadır "Mükellefiyet ve vergi sorumluluğu için kanuni ehliyet şart değildir". Vergi hukukunda kişi kavramının vergi mükellefiyeti nezdinde değerlendirilmesi sürecinde medeni hukuk kapsamında ehil olan ya da olmayan kişilerin hakkında mükellefiyet tesis edilmesi VUK çerçevesinde de gerekli hükümler ile ifade edilmiştir.

\section{KEYKK Kavramının Uluslararası Çerçevedeki Yasal Kapsamı}

Hukukta kişi hak ve borçlara sahip, bunları gerek kendileri gerekse yasal temsilcileri ile kullanan varlık olarak ifade edilmektedir. Kişilere haiz olan hakları ilgilendiren hukuk dalı ise "Medeni Hukuk" olarak nitelendirilmektedir (Gök \& Akçay, 2012: 157). Doğal olarak medeni kanunda belirtilen hak ehliyetinin ölüm ile son bulması vergi hukukunda da ölümün mükellef nezdinde gerçekleşmesi önemli sonuçların tekemmül etmesine bağlanmıştır (Akmaz, 2007: 43). Ölüm ile birlikte fiili hayattan kopma gerçekleşmekte ve doğal olarak kişiliğin sona erme durumu vukuu bulmaktadır. Medeni kanun açısından gerçek kişilerin fiili hayatta işlem tesis edememesi, kişiye ait olan hak ve ehliyetlerin sona ermesi anlamına gelmektedir (Ayan, 2019: 2). Ancak ölüm hali de aynı doğum süreci sonrasında ortaya çıkan birçok hukuki sonucu bünyesinde barındırmaktadır. Bunların başında da ölen kişi açısından vergisel süreçlerin devam etmesi, ölüm ile birlikte yeni bir mükellefiyetin tesis edilmesi sürecidir (Akmaz, 2007: 44). Ölüm, vergi hukukunda değerlendirildiğinde ölen kişiye tarhiyatın yapılamaması fakat söz konusu vergilendirmenin "kanuni veya mansup mirasçılar" nezdinde gerçekleştirilebilmesini sağlayan hukuki bir olaydır. Ayrıca ölümün TVS çerçevesinde bulunan kanunlarda da birtakım sonuçları bulunmakta ve ilgili yasalarda bu minvalde hükümler tesis edilmektedir (Öz vd., 2017: 28).

\subsection{Vergi Kanunları Yönünden Kişiliğin Sona Ermesinin Tesirleri}

Ölümün gerçekleşmesi ile birlikte TMK'nın 18. maddesinde de belirtildiği üzere kişilik son bulmaktadır. Doğal olarak kişinin doğum ile kazandığı hak ehliyeti ve yine yasada belirtilen koşullar dâhilinde şahsın uhdesinde bulunan fiil ehliyeti de sona ermektedir. Ölen kişi medeni kanun çerçevesinde haklarını yitirirken sağlığında vergi mükellefi olması durumunda mükellefiyet yönünden ve mali gücünün vergilendirilmesi açısından birtakım sonuçlar olmaktadır. TMK'nın 599. maddesinde mirasın kazanılmasına yönelik hükümde de sorumluluklar belirtilmiştir "Mirasçılar, miras bırakanın ölümü ile mirası bir bütün olarak, kanun gereğince kazanırlar. Kanunda öngörülen ayrık durumlar saklı kalmak üzere mirasçılar, miras bırakanın aynî haklarını, alacaklarını, diğer malvarlığı haklarını, taşınır ve taşınmazlar üzerindeki zilyetliklerini doğrudan doğruya kazanırlar ve miras bırakanın borçlarından kişisel olarak sorumlu olurlar. Atanmış mirasçılar da mirası, miras bırakanın ölümü ile kazanırlar. Yasal mirasçılar, atanmış mirasçılara düşen mirası onlara zilyetlik hükümleri uyarınca teslim 
etmekle yükümlüdürler". Ölüm ile birlikte vergi kanunları kapsamında hem vergi ödevinin yerine getirilmesi hem de bir tereke söz konusu ise mirasçılar nezdinde malvarlığından kaynaklanan vergisel işlemlerin yapılması gerekmektedir (Akdağ, 2013: 22). VUK'un 12. maddesinde mirasçıların vergi hukuku yönünden sorumlulukları detaylı bir şekilde ifade edilmiştir "Ölüm halinde mükelleflerin ödevleri, mirası reddetmemiş kanuni ve mansup mirasçılarına geçer. Ancak, mirasçılardan her biri ölünün vergi borçlarından miras hisseleri nispetinde sorumlu olurlar". Vergi mükellefinin ölümü ile beraber gerek sağlığındaki vergisel yükümlülük ve borçları açısından gerekse ölüm sonrasındaki hukuki durumlar çerçevesinde TVS'nde bazı sorumluluklar yer almaktadır. Ölüm halinin yani kişiliğinin sona ermesinin TVS’ne etkileri VUK, “193 sayılı Gelir Vergisi Kanunu (GVK)”, "3065 sayılı Katma Değer Vergisi Kanunu (KDVK)”, "6183 sayılı Amme Alacakları Tahsil Usulü Hakkında Kanunu (AATUHK)" ve "7338 sayılı Veraset ve İntikal Vergisi Kanunu (VIVK)" çerçevesinde vukuu bulmaktadır. Ölüm durumunda bahsi geçen kanunlar ve ilişkili yasalarda gerek vergisel sorumluluklar açısından gerekse mirasçılar kapsamında tatbik edilmesi gereken usul ve esas açıdan birçok yükümlülük ortaya çıkmaktadır. Ancak çoğu kimse sorumluluklarının farkında olmamaktadır ve bu yüzden başta vergisel yükümlülükler, başvuru süreleri, zaman aşımı süreleri açısından usul ve esasların tatbiki aşamalarında önemli düzeyde hak kayıpları ortaya çıkabilmektedir. Bu konuda mükellef nezdinde mağduriyetlerin yaşanmaması amacıyla mevzuatta yer alan ve özellik içeren hususlar kapsamında kamuya ve uygulayıcılara bilgilendirmeler yapılmalıdır. Bu yönde gerçekleştirilen yönlendirmeler vasıtasıyla olası hak kayıplarının önüne geçilmesi sağlanacaktır.

\subsubsection{Vergi Usul Kanunu}

Ölen mükellefin Vergi Usul Kanunu kapsamındaki vergisel ödevleri ve sorumlulukları mirasçıları vasıtasıyla yerine getirilmekte, reddi mirasta bulunmamış mirasçılar yükümlü olmaktadır. Bu konu VUK'nun 12. maddesi çerçevesinde ifade edilmiş ve sorumluluk sınırları belirtilmiştir. Söz konusu kanun çerçevesinde muris mükellefin vergisel ödevleri kanuni ve mansup mirasçılarına dâhil olmaktadır. Ayrıca mirası reddetmemiş mirasçılar da hisseleri oranında kişiliği sona erenin vergi borçlarından sorumlu tutulmaktadır. Mirasçılar, murisin ölümünü VUK'un 164. maddesi çerçevesinde vergi dairesine bildirdikten sonra vergi ödevine yönelik yükümlülüklerini diğer mükelleflerin gerçekleştirdikleri şekilde ifa etmek durumundadırlar. Muris mükellefin nihayete ulaşmamış vergilendirmeye yönelik işlemleri için ise kıst vergilendirme dönemi uygulanarak kar-zarar tespiti yapılabilmektedir (Akmaz, 2007: 3). Diğer taraftan mirasçılar tarh ve tahakkuk etmiş ancak ödenmemiş vergi ya da kısmen ödenmiş vergi borçlarından da sorumlu tutulmaktadırlar. Söz konusu ödevleri yerine getirmemek ve borçları ödememek, bildirim ve beyan tarihlerine uymamak yasal ve mansup mirasçılar açısından bir farklılık yaratmamaktadır. Çünkü kanuni ve mansup mirasçıların bu konudaki sorumluluğu külli halefiyet şeklinde tezahür etmektedir (Budak, 2011: 52). Beyan ve bildirimlerin süreleri ölüm olayı ile birlikte VUK'un 16. 
maddesi çerçevesinde uzamaktadır "Vergi kanunlarında hüküm bulunmayan hallerde ölüm dolayısıyla mirasçılara geçen ödevlerin yerine getirilmesinde bildirme ve beyanname verme sürelerine üç ay eklenir". Ancak diğer ödeme ve bildirime yönelik sürelere uyulması gerekmektedir, bu süreler özel süreler hükmünde VUK'un 112. maddesinde şu şekilde belirtilmiştir "Memleketi terk ve ölüm gibi mükellefiyetin kalkmasını mucip haller dolayısıla beyan üzerine tarh olunan vergiler, beyanname verme süreleri içinde ödenir. Mükellefin, vadeleri mezkür süreden sonra gelen vergileri de aynı süre içinde alınır. Memleketi terk edenlerin, ölenlerin veya benzeri haller dolayısıyla mükellefiyetleri kalkanların ikmalen, re'sen veya idarece tarh olunan vergileri tahakkuk tarihinden başlayarak bir ay içinde ödenir". Vergi mükelleflerinin işe başlamayı ve bırakmayı bildirme yükümlülükleri bulunmaktadır. Bu çerçevede ölüm halinde de murisin mükellefiyeti vergi kanunlarına göre işi bırakma hükümleri kapsamında değerlendirilmektedir. Bundan dolayı mirasçılar VUK 164. maddesi bağlamında bildirim yükümlülüğüne haizdir "Ölüm işi bırakma hükmündedir. Ölüm mükellefin mirası reddetmemiş mirasçıları tarafından vergi dairesine bildirilir. Mirasçılardan her hangi birinin ölümü bildirmesi diğer mirasçıları bu ödevden kurtarır". Mirasçıların sorumluluğunun istisnası murisin vergi cezalarına ilişkin olup 2709 sayılı Türkiye Cumhuriyeti Anayasasının 38. maddesi ve 5237 sayılı Türk Ceza Kanunun (TCK) 20. maddesi çerçevesinde "cezaların şahsiliği" hükmüne göre değerlendirilmiştir. Kişiliği ölüm ile sona ermiş şahsın cezai yönden hukuka aykırı fiillerinden dolayı tekrar cezalandırıması da bu minvalde olanak dâhilinde bulunmamaktadır. Bu açıdan VUK'un 372. maddesi bu yönde bir hüküm getirmiştir "Ölüm halinde vergi cezası düşer". Söz konusu cezalar, murisin hukuka aykırı fiillerinden dolayı kendi fiili ile ilgili kesilen cezalarını kapsamaktadır. Fakat vergi aslına bağı ılan ve vergi aslı çerçevesinde tarh, tahakkuk edilen cezalar VUK'nun 372. maddesi kapsamına girmemektedir. Bunlar "gecikme zammı, gecikme faizi, tecil faizi, pişmanlık zammı ve haksız çıkma zammı" olarak değerlendirilmektedir. Çünkü vergi aslına bağlı fer'i kamu alacakları cezai kapsamda değildir ve kişiliğin sona erme halinden etkilenmemektedir. Yani söz konusu fer'i alacaklar muris mükellefin kanuni veya atanmış mirasçılarına intikal etmektedir (Budak, 2011: 63). Bu minvalde Danıştay'ın ceza olarak kabul edilmeyen zam ve faizler açısından aldığı kararlar bulunmaktadır "...vergi ve resimlerin geç ödenmesi sebebiyle istenen zamlar vergi cezası niteliğinde değildir..." (Danıştay, DD, 11.12.1953, E:1953/155, K: 1953/194). TCK'nın 64. maddesi gereğince muris sağlığında vergi yargılamasına muhatap olmuş ve "hürriyeti bağlayıcı ceza" ile cezalandırılmışsa ölüm, cezaya yönelik olan mahkûmiyeti ve buna ilişkin tüm sonuçları ortadan kaldırmaktadır. Eğer muris yaşarken vergi suçları bakımından fail konumunda bulunuyorsa ve soruşturma tahkikat aşamasında ise takipsizlik kararı verilir. Vergi suçu çerçevesinde ceza kesinleşmiş ancak infaz edilmemişse infaz yerine getirilmemektedir. Vergi ödevlerinden bildirime yönelik hükümler sadece murisin mirasçılarına bu sorumluluğu yüklememiştir. Vergilendirme süreci için önemli bir aşama olan "ölüm” birtakım hakların kullanılması, kanuni sürelerin tekemmül etmesi ve kamu alacağının korunması açısından büyük önem arz etmektedir. Bu minvalde bildirim sadece mirasçılara 
bırakılmamış kamu görevlilerinin de bu anlamda sorumluluğu VUK'un 150. maddesi çerçevesinde hüküm altına alınmıştır. Buna göre "Aşağıda yazılı resmi makamlarla gerçek ve tüzel kişiler, her ay muttali oldukları ölüm vakaları ile intikalleri ertesi ayın 15 inci günü akşamına kadar vergi dairesine yazı ile bildirmeye mecburdurlar. Sulh yargıçları, icra, nüfus ve tapu memurları; Yabancı memleketlerdeki Türk konsolosları veya konsolosluk görevini yapanlar (Memur oldukları yerde ölen Türk tebaasının soyadı, adı ve sıfatları ile Türkiye'deki ikametgahlarını Maliye Bakanlığına bildirirler); Mahalle ve köy muhtarları (Kendi mahalle veya köylerinde ölenleri bildirirler); Banka, bankerler ve şirketler ile emanet kabul eden gerçek ve tüzel kişiler (Mevduat, şirket hissesi, emanet para ve eşya veya sair suretle alacak sahiplerinden birinin ölümü halinde, ölenin soyadını, adını, alacağının nev'ini ve miktarını bildirirler)".

\subsubsection{Gelir Vergisi Kanunu}

Ölüm hali ile birlikte kişiliğin sona ermesinin Gelir Vergisi Kanunu kapsamında da önemli neticeleri bulunmaktadır. Gelir vergisi mükellefi olan gerçek kişilerin, ölüm ile birlikte kişiliklerinin sona ermesinin Türkiye dâhiline ve haricindeki gelirleri, malvarlıkları açısından birtakım hükümler ortaya çıkarmaktadır. Bunlar beyanname verme süreleri açısından, mirasçıların murisin işine devam etmesi durumunda ve beyanname verme sürelerine ilişkin değişiklikler göstermektedir (Akmaz, 2007: 44). GVK'nın 84. maddesi çerçevesinde verilmesi gerek beyannameler arasında yer alan beyannamelerde de bildirim zorunluluğu bulunmakla birlikte ölüm halinde süreler özel olarak uzamaktadır. Yıllık beyannamelerin uzamasına yönelik GVK 92/2. maddesinde hüküm yer almaktadır "Takvim yılı içinde memleketi terk edenlerin beyannameleri memleketi terke takaddüm eden 15 gün, ölüm halinde, ölüm tarihinden itibaren 4 ay içinde verilir". Vergi mükellefinin veya vergi sorumlusunun GVK 84. madde minvalinde belirtilen beyannamelerden olan muhtasar ve münferit beyannamede de özel sürelere yönelik düzenleme VUK'un 16. maddesinde belirtilmektedir. Söz konusu madde kapsamında beyanname süreleri "Vergi kanunlarında hüküm bulunmayan hallerde ölüm dolayısıyla mirasçılara geçen ödevlerin yerine getirilmesinde bildirme ve beyanname verme sürelerine üç ay eklenir" hükmünden faydalanmakta ve ilgili beyan sürelerine 3 ay ilave edilmektedir. Murisin gelir vergisi mükellefi olduğu durumda mirasçılar ölenin mesleki faaliyetinden dolayı birtakım istisnalara da haiz olmaktadır. Bunlar GVK'nın 18. maddesi kapsamındaki istisna hükümleri çerçevesinde düzenlenmiş olup ölümün vukuu bulması halinde murisin sadece kanuni mirasçıları için devam etmektedir. Mansup mirasçılar serbest meslek kazancı çerçevesinde belirtilen "telif kazançları istisnası"'ndan faydalanamamaktadır (Gınalı, 2011: 231). Bu kapsamda GVK 18. maddesinde gerekli düzenleme şu şekilde ifade edilmiştir "Müellif, mütercim, heykeltraş, hattat, ressam, bestekar, bilgisayar programcısı ve mucitlerin ve bunların kanuni mirasçılarının şiir, hikaye, roman, makale, bilimsel araştırma ve incelemeleri, bilgisayar yazılımı, röportaj, karikatür, fotoğraf, film, video band, radyo ve televizyon senaryo ve oyunu gibi eserlerini gazete, dergi, bilgisayar ve internet ortamı, radyo, 
televizyon ve videoda yayınlamak veya kitap, $C D$, disket, resim, heykel ve nota halindeki eserleri ile ihtira beratlarını satmak veya bunlar üzerindeki mevcut haklarını devir ve temlik etmek veya kiralamak suretiyle elde ettikleri hasılat Gelir Vergisinden müstesnadır". Kanunda belirtildiği üzere yasal mirasçılar herhangi bir zaman sınırı ile kısıtlanmadan bu istisnadan faydalanmaktadırlar (Budak, 2011: 83). Muris mükellefe ait işyerinin mirasçıları tarafından devralınarak işe devam edilmesine, işyerine ait faaliyetlerin sürdürülebilmesine imkân tanınmıştır. Bu yönde GVK 81/1. maddesi çerçevesinde kolaylık getirilmiştir "Ferdi bir işletmenin sahibinin ölümü halinde, kanunî mirasçılar tarafından işletmenin faaliyetine devam olunması ve mirasçılar tarafından işletmeye dahil iktisadî kıymetlerin kayıtı değerleriyle (bilanço esasına göre defter tutuluyorsa bilançonun aktif ve pasifiyle bütün halinde) aynen devir alınması". Bu madde hükmünden yola çıkarak işletmenin devam etmesi, işletme kişiliğinin devamına yönelik mirasçılara bir fırsat tanındığı söylenebilir. Ancak mirasçıların devriyle ortaya çıkan değer artış kazancından yeni mükelleflerin istisna tutulabilmesi, mirasçıların ferdi işletmenin mukayyet değerleri ile devralınmasını gerektirmektedir (Erdal, 2010: 4). Bu durumda bilançoda yer alan kıymetler açısından oluşan değer artışı vergilendirilmemektedir. Eğer işletmeye dâhil kıymetlerin mirasçılar tarafından devralınması durumunda ayrı bir değerlemeye tabi tutulması sonucu oluşan değer artış kazançları, değer artış kazancı hükmünde kabul edilecek ve dolayısıyla vergilendirilecektir. Bunun yanında mirasçıların tamamının değil, bir ya da birkaçının işletmeyi devralarak faaliyete devam etmeleri halinde doğal olarak mükellefiyet tesisine binaen elde edilen kazançlar ticari kazanç olarak sayılacaktır (Akmaz, 2007: 4).

\subsubsection{Katma Değer Vergisi Kanunu}

Katma Değer Vergisi Kanunu (KDVK) kapsamında değerlendirilen sorumluluk, muris mükellefin mirasçılarının işletmeyi devralarak işe devam edeceklerine ya da devam etmeyeceklerine göre farklılık göstermektedir. İşletmenin mirasçılar tarafından aktif ve pasifleri ile birlikte kül halinde satılması, işletmeye ait kıymetlerin satışı sürecinde de katma değer vergisi hesaplanmayacaktır (Gınalı, 2011: 232). Ancak mirasçıların işletmeyi devralmaları durumunda GVK'nun 81. maddesi çerçevesindeki değer artışı başta olmak üzere 3065 sayılı Katma Değer Vergisi Kanunu'nun 17/4-c maddesi kapsamında vergi hesaplanmamaktadır. Buna göre "Gelir Vergisi Kanununun 81 inci maddesinde belirtilen işlemler ile Kurumlar Vergisi Kanununa göre yapılan devir ve bölünme işlemleri (Bu kapsamda vergiden istisna edilen işlemler bakımından Katma Değer Vergisi Kanununun 30 uncu maddesinin (a) bendi hükmü uygulanmaz. Işslem sonunda faaliyetini bırakan, bölünen veya infisah eden mükelleflerce yüklenilen ve indirilemeyen vergiler, faaliyete başlayan veya devir ve bölünme sonrasında devredilen veya bölünen kurumların varlıklarını devralan mükellefeler tarafından mükerrer indirime yol açmayacak şekilde indirim konusu yapılır)”. Çünkü mezkûr madde gereğince yapılan işlemler devir hükmünde değerlendirilmekte ve GVK ve 5520 sayılı Kurumlar Vergisi hükümlerine göre yapılan devir çerçevesinde gerçekleştirildiği kabul 
edilmektedir. Ayrıca mükelleflerin işletme faaliyetlerine devam sırasında murisin işletmesinde devreden KDV bulunması durumunda işletmeyi devralan mirasçılar söz konusu KDV'yi indirim konusu yapabilecektir (Budak, 2011: 89). Ancak KDV vergi matrahının tespit edilmesi sürecinde gider olarak değerlendirilmemektedir, bu konuda KDVK'nun 58. maddesinde gerekli hüküm yer almaktadır. Buna göre "Mükellefin vergiye tabi işlemleri üzerinden hesaplanan Katma Değer Vergisi ile mükellefçe indirilebilecek Katma Değer Vergisi, Gelir ve Kurumlar Vergisi matrahlarının tespitinde gider olarak kabul edilmez". Murisin adi ortaklıkta yer aldığı bir işletme dâhilinde işlem gerçekleşmesi durumunda kıymetlerin intikalinde veya kollektif şirket ortağının muris olması halinde işletmeye kayıtlı kıymetlerin aynen devralınması faaliyetleri devam ettirmek koşulu ile katma değer vergisinden istisna tutulmaktadır (Akdağ, 2013: 25).

\subsubsection{Amme Alacaklarının Tahsil Usulü Hakkında Kanun}

Amme Alacaklarının Tahsil Usulü Hakkında Kanun (AATUHK) kapsamında ölüme bağlı borçların ödenmesine yönelik düzenlemeler kamu alacağının takip ve tahsili açısından önem arz etmektedir. Vergi mükellefi murisin mirasçıları AATUHK'nun 3. maddesi çerçevesinde borçlu sıfatına haiz olmaktadırlar, şöyle ki "....Amme borçlusu veya borçlu terimi, amme alacağını ödemek mecburiyetinde olan hakiki ve hükmi şahısları ve bunların kanuni temsilci veya mirasçılarını ve vergi mükelleflerini, vergi sorumlusunu, kefili ve yabancı şahıs ve kurumlar temsilcilerini..." ifade etmektedir. Ayrıca amme borçlusunun ölümü durumunda yapılacaklar AATUHK'nun 7. maddesinde şu şekilde belirtilmiştir: "Borçlunun ölümü halinde, mirası reddetmemiş mirasçılar hakkında da bu kanun hükümleri tatbik edilir. Borçlunun ölümünden evvel başlamış olan muamelelere devam olunur. Terekenin bir mahkeme veya iflas dairesi tarafından tasfiyesini gerektiren haller bu hükmün dışındadır. Mirasın tutulan defter mucibince kabulü halinde, mirasçı, deftere kaydedilmemiş olsa dahi amme alacağından mirastan kendisine düşen miktar ile mesuldür. Defter tutma muamelesinin devamı müddetince satış yapılamaz". Murisin ölümünden önce vergi borcu kapsamında bir tebligat yapılmış ise söz konusu tebligata murisin sağlığında dava açılmamış veya dava süresi geçmiş, vergi davasını kaybetmiş ve sonrasında borçlu ölmüş ise doğal olarak kamu borcunun terekeden karşılanması söz konusu olacaktır. Eğer murisin ölümünden önce borca ilişkin haciz süreci başlatılmışsa kamu borcunun terekeden karşılanabildiği ölçüde tatmini gereklidir. Aksi durumda terekenin yetersiz olması halinde tabii ki reddi mirasta bulunmamış mirasçılar takip edilecektir (Budak, 2011: 71).

Murisin ölmeden ödeme emrine karşı açtığı bir dava bulunmakta ise 2577 sayılı İari Yargılama Usulü Kanunu'nun 26. maddesine göre hareket edilmektedir, buna göre "Dava esnasında ölüm veya herhangi bir sebeple tarafların kişilik veya niteliğinde değişiklik olursa, davayı takip hakkı kendisine geçenin başvurmasına kadar; gerçek kişilerden olan tarafın ölümü halinde, idarenin mirasçılar aleyhine takibi yenilemesine kadar dosyanın işlemden kaldırılmasına ilgili mahkemece karar verilir. Dört ay içinde yenileme dilekçesi verilmemiş ise, varsa yürütmenin durdurulması kararı kendiliğinden 
hükümsüz kalır. Yalnız öleni ilgilendiren davalara ait dilekçeler iptal edilir". Borcun takibine yönelik olarak AATUHK'nun 50. maddesi çerçevesinde ölüm halinin hemen sonrasında belirli bir süre "takibin geri bırakılması" hakkı yer almaktadır, buna göre "Karısı yahut kocası, kan ve sıhriyet itibariyle usul veya füruundan birisi ölen borçlu hakkındaki takip ölüm günü ile beraber üç gün için geri bırakılır. Borçlunun ölümü halinde terekenin borçlarından dolayı ölüm günü ile beraber üç gün için takip geri bırakılır. Üç günün bitiminde terekenin borçları için takibata devam olunur. Mirasçılar, mirası kabul veya ret etmemişlerse bu hususta Medeni Kanundaki muayyen müddetler geçinceye kadar takip geri bırakılır".

Murisin ayrıca vergiye ilişkin borçları bulunmakta ise farklı uygulama söz konusudur. Vergi borçlarında VUK 12. madde kapsamında mirasçıların hisseleri oranında sorumlulukları belirlenirken, bu borçlar haricinde vukuu bulan diğer borçlar MK'nun 641. maddesine göre tereke borçlarından müteselsilen talep ve tahsil edilmektedir. "Mirasçılar, tereke borçlarından müteselsilen sorumludurlar. Ana ve baba veya büyük ana ve büyük baba ile birlikte yaşayan ve emeklerini veya gelirlerini aileye özgüleyen ergin çocuklar ile torunlara verilecek uygun miktardaki tazminat, bu yüzden terekenin borç ödemeden acze düşmemesi kaydıyla tereke borcu sayılır". Ancak ilgili madde kapsamındaki sorumluluk "Mirasçılar, bölünmesine veya nakline alacaklı tarafından açık veya örtülü olarak rıza gösterilmemiş olan tereke borçlarından dolayı, paylaşmadan sonra da bütün malvarlıklarıyla müteselsilen sorumludurlar. Paylaşmanın gerçekleştiği tarihin veya daha sonra yerine getirilecek borçlarda muacceliyet tarihinin üzerinden beş yıl geçmekle teselsül sona erer" hükmüyle birlikte "mütesesilen talep edilebilme" hali 5 yılın bitiminde sona ermektedir.

\subsection{Kişiliğin Sona Ermesinin Ölüm Sonrasında Ortaya Çıkan Mükellefiyete Etkisi}

Ölüm, kişiliğin ve ona bağı hakların sona ermesidir ancak mirasçılar açısından yeni bir hukuki sürecin, ödev ve sorumlulukların başlaması anlamına gelmektedir (Aslan, 2011: 129). Bu minvalde murisin malvarlığı yani terekenin mirası reddetmemiş mirasçılara intikal etmesi veraset ve intikal vergisinin konusunu oluşturmaktadır. Bu aşamada mirasçıların gerek beyanname ve buna yönelik ödevler, gerekse veraset ve intikal vergisinin ödenmesi doğrultusunda yükümlülükleri doğmaktadır (Arıca, 1999: 10). Veraset ve intikal vergisi, veraset yoluyla ivazsız iktisap eden veya her ne şekilde olursa olsun ivazsız edinilen mal ve kıymetler için ödenmektedir. Bu yüzden gerçek kişilerin ölümü dolayısıyla mirasçılarına intikal eden tereke malları bir anlamda verginin konusunu oluşturmaktadır (Gınalı, 2011: 236). Söz konusu verginin konusu 7338 sayılı Veraset ve İntikal Vergisi Kanunu'nun (ViV) 1. maddesinde açıkça ifade edilmiştir. Buna göre "Türkiye Cumhuriyeti tabiyetinde bulunan şahıslara ait mallar ile Türkiye'de bulunan malların veraset tarikiyle veya her hangi bir suretle olursa olsun ivazsı bir tarzda bir şahıstan diğer şahsa intikali Veraset ve intikal Vergisine tabidir. Bu vergi, Türk tabiiyetinde bulunan şahısların ecnebi memleketlerde aynı yollardan iktisab edecekleri mallara da şamildir. Türkiye Cumhuriyeti tabiiyetindeki bir şahsın Türkiye 
hudutları dışında bulunan malını veraset tarikıyle veya sair suretle ivazsız bir tarzda iktisab eden ve Türkiye'de ikametgahı olmayan ecnebi şahıs bu vergi ile mükellef tutulmaz". Yani Türk vatandaşı kişinin malının Türkiye'de olması ve Türkiye Cumhuriyeti (T.C.) vatandaşlığı bulunması halinde ikametgâhının Türkiye içinde ya da dışında olması veraset ve intikal vergisinin konusuna girmesine engel teşkil etmez. Diğer taraftan Türk vatandaşı gerçek kişinin malının Türkiye dışında olması durumunda ikametgâhı Türkiye'de olan T.C. vatandaşına veraset vergisinin konusuna giren malların intikal etmesi durumunda veraset vergisi söz konusu olmaktadır (Şenyüz vd., 2021b: 430). Vergiyi doğuran olay ise Viv kanununun 2. maddesinde belirtilen "...mülkiyete mevzu olabilen menkul ve gayrimenkul şeylerle mameleke girebilen sair bütün hakları ve alacakları..." düzenlemesi uyarınca malların kanunun 1. maddesinde zikredilen kişilere veraset yoluyla ya da herhangi bir şekildeki ivazsı iktisabı ile gerçekleşmektedir. Başka bir ifade ile vergiyi doğuran olayın vukuu bulması; ölümün gerçekleşmesi, kişiye yönelik verilen gaiplik kararı veya kişinin sağlığında yaptığı ivazsız intikaller (bağış v.b.) vasıtasıyla meydana gelmektedir (Gelir İdaresi Başkanlığı, 2014: 2).

ViV kapsamında muafiyet ve istisnalar da tanınmıştır, bu minvalde muafiyetler ViV yasasının 3. maddesinde belirtilmiştir. Söz konusu maddeye göre "Amme Idareleri, emekli ve yardım sandıkları, sosyal sigorta kurumları, umumi menfaata hadim cemiyetler, siyasi partiler ve bunlara ait olan veya bunların aralarında kurdukları teşekküllerden Kurumlar Vergisine tabi olmayanlar; yukarıdaki fıkrada sayılanlar dışında kalan hükmi şahıslara ait olup umumun istifadesi için ilim, araştırma, kültür, sanat, sıhhat, eğitim, din, hayır, imar, spor gibi maksatlarla kurulan teşekküller; yabana Devletlerin Türkiye'de bulunan elçi, maslahatgüzar ve konsolosları (Fahri konsoloslar hariç) ile elçilik ve konsolosluklara mensup olan ve o Devletin tabiiyetinde bulunun memurları ve Türkiye'de resmi bir vazifeye memur edilenler ile bu sayılanların aileleri efradı (Mütekabiliyet şartiyle) (Türk tabiiyetinde bulunan şahıslardan veraset tarikılle veya sair suretle mal iktisab edenlerle yukarda sayılanların dışında kalıp da Türkiye'de ikamet eden şahısların Türkiye'de bulunan mallarını veraset tarikıyla veya sair suretle iktisab edenler hariç)". Diğer yandan 7338 sayılı kanunun 4. maddesi çerçevesinde istisna hükümleri detaylı bir şekilde yer almaktadır ancak söz konusu hükümlerden parasal hadlere göre istisnalar ve kişisel eşyalara ait düzenleme şu şekilde belirtilmektedir "Veraset tarikı ile intikal eden ev eşyası ile murise ait zat eşyası ve aile hatırası olarak muhafaza edilen tablo, kılıç, madalya gibi eşya, örf ve adete göre verilmesi mütat bulunan hediye, cihaz, yüzgörümlüğü ve drahomalar (Gayrimenkuller hariç); değerleri 10 uncu maddeye göre (matrahın tayin edilmesi) belirlenen menkul ve gayrimenkul mallardan evlatlıklar da dahil olmak üzere füruğ ve eşten her birine isabet eden miras hisselerinin $334.534 \mathrm{TL}$ 'sı (füruğ bulunmaması halinde eşe isabet eden miras hissesinin $669.479 \mathrm{TL}$ 'sl; ivazsız suretle vaki intikallerin $7.703 \mathrm{TL}$ 'sl; para ve mal üzerine düzenlenen yarışma ve çekilişler ile 14/3/2007 tarihli ve 5602 sayılı Şans Oyunları Hasılatından Alınan Vergi, Fon ve Payların Düzenlenmesi Hakkında Kanunda tanımlanan şans oyunlarında kazanılan ikramiyelerin 7.703 TL'sı" (Resmi Gazete, 
2020/52: 4). ViV kanunu kapsamında her yıl yeniden değerleme oranında arttırılan istisna tutarları 4. madde çerçevesinde hüküm altına alınmıştır.

Gaiplik gibi sebeplerle kişiliği sona eren ve ölmüş olarak addedilen murisin mirasçılarına yasalar, yerine getirilmesi gereken birtakım ödevler vermektedir. Söz konusu durum minvalinde mirasçıların, ViV kanunundaki hükümler çerçevesinde belirtilen yükümlülükleri dikkate alarak hareket etmeleri kanuni sürecin doğru tekemmül etmesi açısından önem arz etmektedir. Mirasçıların öncelikle ölen kişinin mirasçısı olduklarını belirten, hangi oranlarda hisselere sahip olduklarını gösteren ve mirasçı olduklarının hukuksal olarak ispat eden veraset ilamı (mirasçılık belgesi) almaları gerekmektedir (Akdağ, 2013: 23). Mirasçılık belgesi herhangi bir yerin sulh hukuk mahkemesinden (işlemlerin daha hızı ilerlemesi açısından murisin nüfus kaydının olduğu mahkeme) alınabilmektedir (Gelir İdaresi Başkanlığı, 2014: 1). Ayrıca "6217 sayılı Idari Yargı Hizmetlerinin Hızlandırılması Amacıyla Bazı Kanunlarda Değişiklik Yapılmasına Dair Kanun ile 1512 sayılı Noterlik Kanunu" 'nda yapılan değişikliğe göre veraset ilamının noterlerden de alınabilmesi sağlanmıştır (Resmi Gazete, 2011/6217: 14).

ViV kapsamında mükellefiyetin başlaması 7338 sayılı yasanın 20. maddesinde belirtilmiştir. Buna göre, mükellefiyet "Veraset ve intikal Vergisi mükellefiyeti: Beyanname verildiği takdirde, beyannamede gösterilen mallar için beyanname tarihinde; Verilen beyannamede gösterilmeyen mallar ile beyanname verilmeyen hallerde intikal eden malların idarece tespit olunduğu tarihte; Terekenin tahriri, defter tutma veya resmi tasfiye hallerinde mahkemece bu muamelelerin ikmal edildiği tarihte" başlamaktadır. Öncelikle miras vasıtasıyla intikal eden malların VUK hükümlerinde belirtilen esaslar çerçevesinde bulunan değerlerinden, viv Kanunu'nun 12. maddesinde hüküm altına alınmış olan borç ve masraflar indirilmekte ve matrah bulunmaktadır. Daha sonra mükellefler ilk tarhiyatta kullanılmak üzere ViV'nin konusu kapsamındaki kıymetleri yasanın 10. maddesi çerçevesinde değerlemektedirler. İkinci tarhiyat vergi dairesi tarafından yapılacak olup mirasçıların beyanı sonrasında tarhiyata ilave matrah veya indirimler uygulanması suretiyle matrahın son aşamada tayini yapılmaktadır (Budak, 2011: 120).

Beyanname matrah tayin ve kontrollerinin yapılması ile viV kanununun 8. maddesinde belirtilen yerlere verilebilmektedir, bunlar "veraset ve intikal vergisi beyannameleri, veraset tarikiyle vuku bulan intikallerde ölen kimsenin, diğer suretle vuku bulan intikallerde tasarrufu yapan şahsın ikametgâhının, hükmî şahıslarda ve diğer teşekküllerde merkezlerinin bulunduğu yer vergi dairesine verilecek, muris veya tasarrufu yapan şahıs Türkiye'de hiç ikamet etmemiş veya son ikametgâhı tespit edilememiş ise Maliye Bakanlı̆̆ı'na verilecek ve vergi tarhiyatı Bakanlıkça tâyin olunacak mahal vergi dairesince yapılacaktır. Yabancı memleketlerde bulunan mükellefler beyannamelerini o memleketlerdeki Türkiye konsolosluklarına vereceklerdir". Ayrıca ölüme bağlı ivazsız intikaller çerçevesinde düzenlenen beyannamelerin verilme süreleri de herhangi bir cezai durumun gerçekleşmemesi 
adına önem arz etmektedir. Söz konusu süreler ViV Kanunu'nun 9. maddesinde şu şekilde hüküm altına alınmıştır: "Veraset tarikiyle vukuu bulan intikallerde: Ölüm Türkiye'de vukuu bulmuş ise mükelleflerin Türkiye'de bulunmaları halinde ölüm tarihini takip eden dört ay içinde, mükelleflerin yabancı bir memlekette bulunmaları halinde ölüm tarihini takip eden altı ay içinde; Ölüm yabancı bir memlekette vukuu bulmuş ise mükelleflerin Türkiye'de bulunmaları halinde ölüm tarihini takip eden altı ay içinde, mükellefler müteveffanın bulunduğu memlekette oldukları takdirde ölüm tarihini takip eden dört ay içinde, mükellefler müteveffanın bulunduğu yerin dışında başka bir yabancı memlekette oldukları takdirde de ölüm tarihini takip eden sekiz ay içinde; Gaiplik halinde, gaiplik kararının ölüm siciline kaydolunduğu tarihi takip eden bir ay içinde; Diğer suretle vakıa intikallerde malların hukuken iktisap edildiği tarihi takip eden bir ay içinde" beyan edilmelidir. Verginin ödenmesi Viv kanunun 19. maddesinde belirtildiği üzere, "Veraset ve intikal vergisi tahakkukundan itibaren (3) yılda ve her yıl mayıs ve kasım aylarında olmak üzere iki eşit taksitte" nihayete ermektedir. Aksi yöndeki uygulamalarda yani sürelerin geçirilmesi, kanunda bulunan ek sürelerin de verilmesine rağmen herhangi bir ödemenin yapılmaması durumunda "vergi ziyaı cezası ve gecikme faizi" söz konusu olacaktır. ViV'in 21. Maddesi gereği gaibin zuhur etmesi durumunda gaip mirasçının ve gaibin zuhuru şeklinde düzenleme yer almaktadır, bu durum yasada şu şekilde ifade edilmiştir "Gaip mirasçının zuhuru: gaip mirasçının zuhuru dolayısı ile evvelce tahakkuk eden ViV'nin tadili icab ettiği takdirde zuhur eden mirasçının vereceği beyannameye veya vergi dairesince yapılacak idare tahkikata göre sabit olacak matrah üzerinden vergi düzeltilir. Gaip murisin zuhuru: Gaip muris zuhur ettiği takdirde nüfustaki ölüm kaybının terkinini müteakip, evvelce alınmış olan vergiler talep üzerine mükellefe geri verilir".

Gerek devlet gerekse mükellefler açısından ViV beyan ve ödemesinin sorunsuz nihayetlendirilmesi önemlidir. Olası hak kayıplarının ve bilgi eksiliğinden kaynaklanan vergi cezalarının önüne geçilmesi için mükellefin bilgilendirilmesi şarttır. Vergi adaletine uyulması açısından birçok yasa ile etkileşimde bulunan viV kanunda yer alan uygulamalar konusunda detay bilgilendirme çalışmaları yapılması idarenin bir görevi konumundadır. Ayrıca ekonomik şartlar ışığında muafiyet, istisna ve indirimlerin güncellenmesi mükellef aidiyeti açısından önem arz etmektedir.

\section{Sonuç}

Muasır medeniyet mertebesindeki hukuk sistemlerinde tüm insanlar gerçek kişi olarak kabul edilmektedir ve doğal olarak hukuksal temelde kişi bir hak süjesi olarak yer almaktadır. Bu minvalde Türk Medeni Hukukunda da kişi kavramı net bir şekilde ifade edilmiş, kişiye doğum ile birlikte hak ehliyeti tanınmıştır. Tüm insanların hukuk düzeni çerçevesinde haklara ve borçlara ehil olma yönünde kabul edilen evrensel gerçeklik, Türk Medeni Kanunu'nun 28. maddesinde "Kişilik, çocuğun sağ olarak tamamıyla doğduğu anda başlar ve ölümle sona erer. Çocuk hak ehliyetini, sağ doğmak koşuluyla, ana rahmine düştüğü andan başlayarak elde eder" şeklinde ifade edilmiştir. 
Yani insanlık âlemindeki hak öznesinin "kişi" olarak kabul edilmesi Türk Hukuk düzeninde yasal bir temele sahip olması sağlanmıştır.

Doğum ile başlayan hak ehliyeti, yasalar çerçevesindeki özellikler kapsamında oluşan fiil ehliyeti yaşamın ölüm ya da gaiplik vasıtasıyla son bulması üzerine nihayetlenmektedir. Bu durumun doğal sonucu olarak murisin mirasçıları da ölüm sonrası birtakım hak ve yükümlülüklere haiz olmaktadır. Kişiliğin sona ermesi TVS'nde birçok farklı sonuç ortaya çıkarmaktadır. Bu kapsamda ölüm hali murisin mükellefiyetini ortadan kaldırsa da mirasçılarına yeni maddi ve şekli vergisel yükümlülükler, sorumluluklar getirmektedir. Ölüm halinde muris mükellefin vergi kanunlarından kaynaklanan ödevleri mirasçılarına geçmektedir. Murisin sağlığında yerine getirmesi gereken "vergi ödeme, beyan, bildirim, saklama ve ibraz" gibi vergisel ödevleri reddi mirasta bulunmamış mirasçıları tarafından yerine getirilmesi gereken bir sorumluluk teşkil etmektedir. Ayrıca murisin mal varlığının mirasçı ya da mirasçılar nezdinde veraset yoluyla ivazsız iktisabı sonucu oluşan veraset ve intikal vergisi ve buna yönelik maddi ve şekli ödevlerinin de yerine getirilmesi gerekmektedir.

Kişiliğin sona ermesi ile birlikte TVS dâhilindeki kanunlar kapsamında birçok farklı sonuç tekemmül etmektedir. Hayatın olağan akışı esnasında vergi sistemini ilgilendiren sayısız değişik olay, işlem yaşanmakta ve doğal olarak TVS bünyesinde çeşitli saik ve sonuçlara sebebiyet vermektedir. Hayatın değişen şartları ve ihtiyaçları doğrultusunda mer'i mevzuatın da ilave düzenlemeler intikal ettirilerek geliştirilmesi ve güncellenmesi elzemdir. Veraset ve intikal vergisinde yer alan muafiyetlerden olan kamusal muafiyetler, kamu yararı amacı güden teşekküllere sağlanan muafiyetlerin genişletilerek kurumsal yapılanmaya ayak uydurulması sağlanmalıdır. Beyanname verme sürelerinden "ivazsı intikallerde verilmesi gereken beyan süresi"'nin 1 ay'dan 2 ay’a çıkarılması mükellefin yanlış işlemler yapmasını engellemek açısından önemlidir. Diğer taraftan beyannamenin doldurulması aşamasında mirasçılar tarafından onay süresi olan 10 günlük zaman dilimi, uygulamada yetersiz kalmakta olup onay süresinin 20 güne çıkarılması olası hak kayıplarının önlenmesi açısından yerinde olacaktır. Başta ivazsız intikallerde belirlenen istisna sınırları olmak üzere tüm istisna sınırlarının günün ekonomik koşulları dikkate alarak arttırılması vergi adaletinin sağlanması açısından da önem arz etmektedir. Ayrıca ölüm olayı sonrasında yapılması gereken iş ve işlemlerin, yasal hak ve borçların başta uygulayıcı statüsünde bulunan mali müşavir ve yeminli müşavirlere, vatandaşlara devletin yetkili organları aracılığıyla bilgilendirilmesi yapılmalıdır. Söz konusu bilişim faaliyetleri yazılı, görsel basın ve sosyal medya aracılığıyla gerek rehber, kılavuz gibi kaynaklarla gerekse seminer, panel, v.b. etkileşim yolları ile geliştirilmelidir. Bu minvalde ortaya konan her türlü bilgi ve yönlendirme kamu alacağının yerinde, doğru, tam ve zamanında tahsil edilmesi açısından faydalı olacaktır. 


\section{Kaynakça}

Budak, T. (2011). Türk Vergi Hukukunda Kişiliğin Sona Ermesi ve Sonuçları, 1. Baskı, On İki Levha Yayıncılık, İstanbul.

Erdal, Ö., (2010). "Vergi Usul Kanunu'nda Ölüm ve Sonuçları", Vergi Sorunları Dergisi, 262, 1-10.

Ergün Ö. (2017). "Kişi Kavramı ve Çeşitleri”, Dicle Üniversitesi Adalet Meslek Yüksekokulu Dicle Adalet Dergisi, 1(1), 1-14.

Gelir İdaresi Başkanlığı, (2014). Mirasçıların Vergisel Yükümlülükleri Rehberi, Mükellef Hizmetleri Daire Başkanlığı, Ankara.

Gınalı, A., (2011). "Mükellefin Ölümü Halinde Mirasçıların Sorumluluğu", Mali Çözüm Dergisi, 103, 231-238.

Gök, A. \& Akçay, F., (2012). "Vergi Hukukunda Kişilik Kavramının İncelenmesi”, Vergi Sorunları Dergisi, 286, 156-170.

Guzy, M.J., (2017). "The principles of tax law equality in the context of direct taxation", Journal of Economics and Management, 30(4), 70-84.

Kirazcı E. (2011). “Ferdi Bir İşletme Sahibinin Ölümü Halinde Mirasçıların GVK ve VUK Çerçevesinde Sorumluluk ve Ödevleri”, Vergi Denetmenleri Derneği, 15-24.

Oğuzman, K., Seliçi, Ö. \& Özdemir O. (2020). Kişiler Hukuku, 19. Baskı, Filiz Kitabevi, İstanbul.

Öcal, Ş. A. (2016). Medeni Hukuk-I, T.C. Anadolu Üniversitesi Açıköğretim Fakültesi Yayını, 8. Baskı, Eskişehir.

Öncel, M., Çağan, N. \& Kumrulu, A. (1985). Vergi Hukuku, 2. Baskı, Ankara Üniversitesi Siyasal Bilgiler Fakültesi Yayınları, Ankara.

Öz, E., Yavuz E., \& Akçay, F., (2017). “Ölüm Vakalarının Türkiye'de Vergisel Açıdan Doğurduğu Sonuçlar", Türkiye Adalet Akademisi Dergisi, 31, 27-45.

Şenyüz, D., Yüce, M. \& Gerçek, A. (2021a). Vergi Hukuku, 12. Baskı, Ekin Basım Yayın Dağıtım, Bursa.

Şenyüz, D., Yüce, M. \& Gerçek, A. (2021b). Türk Vergi Sistemi, 18. Baskı, Ekin Basım Yayın Dağıtım, Bursa.

6183 Sayılı Amme Alacaklarının Tahsil Usulü Hakkında Kanun, (1953, 21 Temmuz), Resmi Gazete (Sayı 8469).

7338 Sayılı Veraset ve İntikal Vergisi Kanunu, (1959, 08 Haziran), Resmi Gazete (Sayı 10231).

193 Sayılı Gelir Vergisi Kanunu, (1960, 31 Aralık), Resmi Gazete (Sayı 10700). 
Ercan, T. (2021). "Gerçek Kişiler Yönünden Kişiliğin Sona Erme Halinin Türk Vergi Sistemindeki Etkisi”, International Journal of Public Finance, 6(2), 291-311.

213 Sayılı Vergi Usul Kanunu, (1961, 04 Ocak), Resmi Gazete (Sayı 10703).

2577 Sayılı İdari Yargılama Usulü Kanunu, (1982, 06 Ocak), Resmi Gazete (Sayı 17580).

2709 Sayılı Türkiye Cumhuriyeti Anayasası, (1982, 18 Ekim), Resmi Gazete (Sayı 17863).

3065 Sayılı Katma Değer Vergisi Kanunu, (1984, 25 Ekim), Resmi Gazete (Sayı 18563).

4721 Sayılı Türk Medeni Kanunu, (2001, 22 Kasım), Resmi Gazete (Sayı 24607).

5237 Sayılı Türk Ceza Kanunu, (2004, 26 Eylül), Resmi Gazete (Sayı 25611).

5520 Sayılı Kurumlar Vergisi Kanunu, (2006, 13 Haziran), Resmi Gazete (Sayı 26205).

6217 Sayılı Yargı Hizmetlerinin Hızlandırılması Amacıyla Bazı Kanunlarda Değişiklik Yapılmasına Dair Kanun, (2011, 14 Nisan), Resmi Gazete (Sayı 27905).

52 Seri No.lu Veraset ve İntikal Vergisi Kanunu Genel Tebliği, (2020, 29 Aralık), Resmi Gazete (Sayı 31349).

Danıştay, DD, 11.12.1953, E:1953/155, K: 1953/194 